\title{
High Rate of IgE-Mediated Histamine Release from Rat Mesenteric Mast Cells
}

\author{
Naoki INAGAKI, Hirokazu KAWASAKI, and Hiroichi NAGAI
}

Department of Pharmacology, Gifu Pharmaceutical University

5-6-1 Mitahorahigashi, Gifu 502-8585, Japan

\begin{abstract}
IgE-dependent histamine release from rat mesenteric mast cells was investigated. Excised mesenterium was cut into pieces and incubated with $\mathrm{IgE}$ overnight at $4^{\circ} \mathrm{C}$ for sensitization. Over 10 pieces of mesenterium specimen could be prepared from a rat. Antigen-induced histamine release from mesenterium specimen was initiated rapidly and reached a plateau in $5 \mathrm{~min}$. In an optimal condition, over $50 \%$ of total histamine was released. In contrast, unpurified and purified peritoneal mast cells released only $22.5 \%$ and $5.3 \%$ of total histamine, respectively, upon IgE stimulation. Tranilast, a mast cell stabilizer, inhibited the histamine release from mesenteric mast cells significantly. The mesenterium might be a useful material for studying tissue-associated mast cell activation.
\end{abstract}

Key words: histamine release, mast cell, rat mesenterium

Abundant mast cells present in the rat peritoneum are widely used for pharmacological and biochemical studies, because they are obtained as single cells and can be purified easily $[3,9]$. In the unpurified preparation, peritoneal mast cells sensitized with $\operatorname{IgE}$ and challenged with a specific antigen release $20-30 \%$ of total histamine. Once purified, however, mast cells release only about $10 \%$ of total histamine. The reduced IgE-dependent histamine release from purified mast cells could be recovered by reconstitution with separated cells $[4,5]$. These results indicate that IgEdependent activation of mast cells is regulated by surrounding cells. Regulation of mast cell activation by surrounding cells might play important roles not only physiologically but also pathophysiologically. Abundant mast cells reside also in the mesenterium of rats, which have been employed occasionally for evaluating anti-allergenic agents [7]. Degranulation of mast cells in mesenterium has been observed under light microscopy. In the present study, therefore, an experimental condition for histamine release was examined using rat mesenterium to establish a model for the activation of tissue-buried mast cells.

Male Wistar rats, weighing about 250-300 g, purchased from Japan SLC (Hamamatsu, Japan) were used. Rat anti-dinitrophenol (DNP) monoclonal IgE was prepared as reported previously [4]. The IgE titer of the preparation estimated by homologous passive cutaneous anaphylaxis was $1: 2,000$ or greater. DNP-conjugated bovine serum albumin (DNP-BSA) was prepared according to the method described by Eisen et al. [2] and used as an antigen to stimulate 

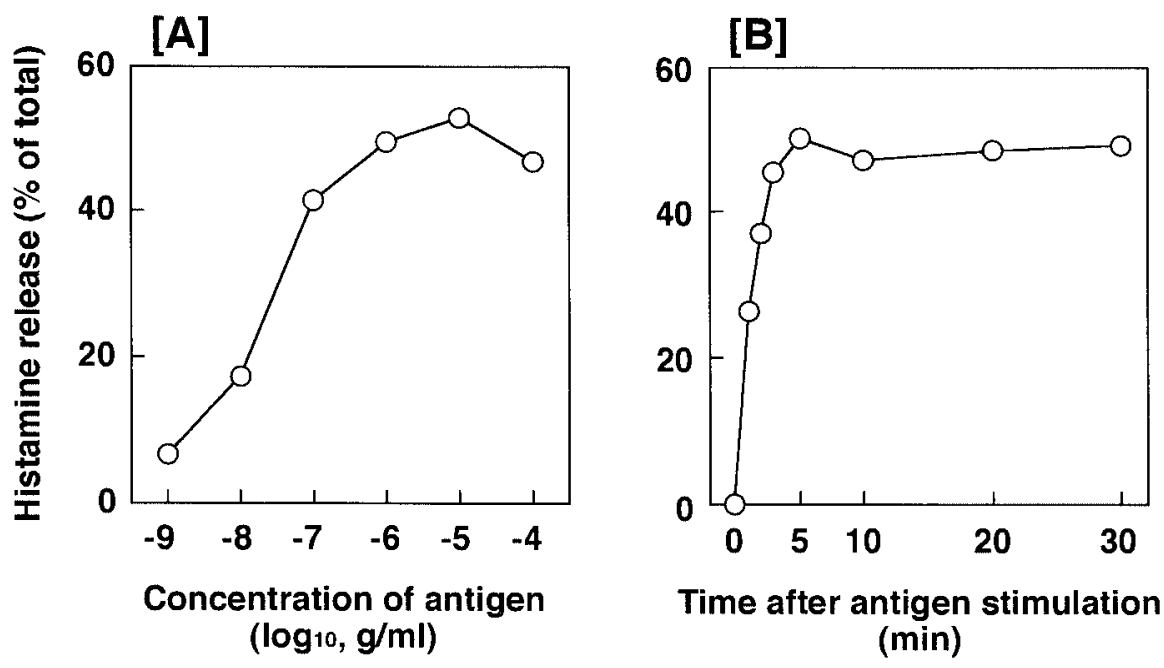

Fig. 1. Dose-response and kinetic studies on histamine release from mesenterium. [A] Sensitized mesenterium was incubated with $0.001-100 \mu \mathrm{g} / \mathrm{m} l$ antigen for $30 \mathrm{~min}$. [B] Sensitized mesenterium was incubated with $1 \mu \mathrm{g} / \mathrm{m} l$ antigen for 0-30 min. A typical result of a duplicated experiment is shown.

sensitized mast cells. The number of DNP residues introduced was 25 in a BSA molecule. Tyrode's solution containing HEPES and gelatin $(137 \mathrm{mM} \mathrm{NaCl}, 2.7$ $\mathrm{mM} \mathrm{KCl}, 0.41 \mathrm{mM} \mathrm{NaH} \mathrm{PO}_{4}, 1.6 \mathrm{mM} \mathrm{CaCl}_{2}, 1 \mathrm{mM}$ $\mathrm{MgCl}_{2}, 0.1 \%$ glucose, $10 \mathrm{mM}$ HEPES, $0.05 \%$ gelatin, $\mathrm{pH}$ 7.4) was used throughout.

Rats were sacrificed under ether anesthesia. Then the mesenterium was excised and cut into pieces in Tyrode's solution. The mesenterium was partitioned by blood vessels into many triangular blocks. Mesenterium specimens containing two triangular blocks were prepared from mesenterium attached to lower small intestines. Over 10 specimens with a similar size could be prepared from a rat. The mesenterium specimens were incubated in a 20 -fold diluted rat monoclonal IgE preparation at $4^{\circ} \mathrm{C}$ overnight for sensitization. The mesenterium specimens were rinsed with Tyrode's solution, and then incubated in Tyrode's solution at $37^{\circ} \mathrm{C}$ for $1 \mathrm{hr}$ to remove unbound IgE. A piece of mesenterium specimen placed in a tube in Tyrode's solution was incubated in the presence of DNP-BSA. After incubation at $37^{\circ} \mathrm{C}$, the reaction was terminated and the mesenterium was removed. The remaining reaction mixture was centrifuged at $350 \times \mathrm{g}$ for $10 \mathrm{~min}$ and the supernatant was separated. Unreleased histamine was extracted from the mesenterium specimen at $37^{\circ} \mathrm{C}$ for $30 \mathrm{~min}$ in the presence of $1.2 \% \mathrm{HClO}_{4}$. We confirmed that $96 \%$ of tissue-associated histamine could be extracted under this condition.

To compare the histamine release from mesenterium to that from peritoneal mast cells, IgE was injected intraperitoneally for sensitization of peritoneal mast cells. Next day, rats were sacrificed under ether anesthesia, and peritoneal cells were recovered. Histamine release from unpurified and purified preparations of peritoneal mast cells was examined as reported previously $[4,5]$.

Histamine in the supernatant was measured fluorometrically by a post-column derivatization method on an automated histamine analyzing system (Tosoh Co., Ltd., Tokyo, Japan) [10]. Total histamine of the mesenterium specimen was calculated as the sum of the released and unreleased histamine. Spontaneous release was $2 \%$ of total histamine or lower.

Results of the dose-response study are shown in Fig. 1A. Sensitized mesenterium specimens were incubated with $0.001-100 \mu \mathrm{g} / \mathrm{m} l$ antigen for $30 \mathrm{~min}$. A bellshaped dose-response curve was obtained, and over $50 \%$ of total histamine was released at an optimal antigen concentration, $10 \mu \mathrm{g} / \mathrm{m} l$. The dose-response curve is almost comparable to that obtained with peritoneal mast cells reported previously [4, 5]. Results of the kinetic study are shown in Fig. 1B. Histamine release was caused by $1 \mu \mathrm{g} / \mathrm{m} l$ antigen. Histamine release was ini- 


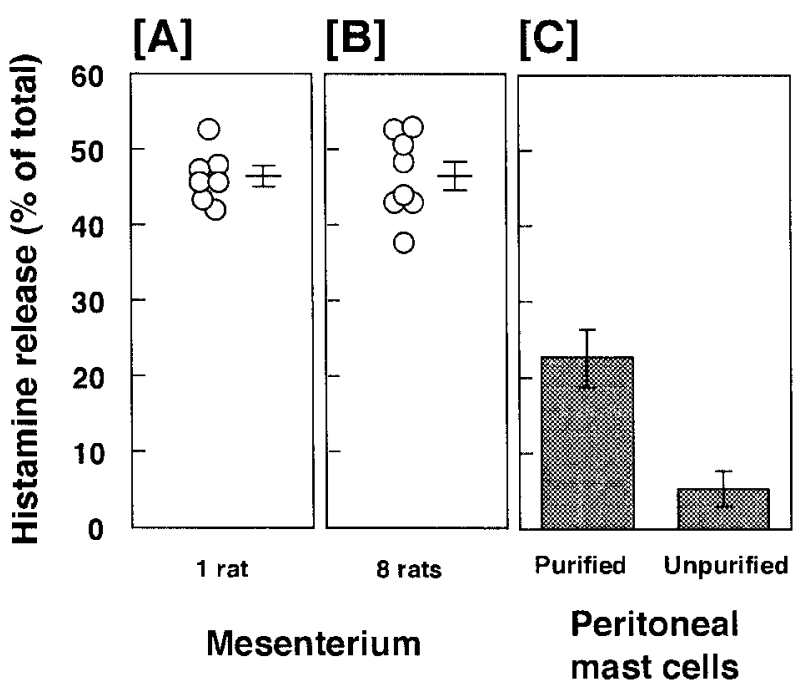

Fig. 2. Comparison of histamine release between mesenterium and peritoneal mast cells. [A] Eight mesenterium specimens were prepared from a rat. Sensitized specimens were incubated with $1 \mu \mathrm{g} / \mathrm{m} l$ antigen for $15 \mathrm{~min}$. One specimen was for spontaneous release. Bars indicate mean \pm SEM. [B] Mesenterium specimens were prepared from 8 rats. Two specimens were selected at random from each rat (one for spontaneous release and the other for antigen stimulation). Sensitized specimens were incubated with $1 \mu \mathrm{g} / \mathrm{ml}$ antigen for $15 \mathrm{~min}$. Bars indicate mean \pm SEM. [C] Peritoneal cells were recovered from sensitized rats. A portion of the cells was purified by density gradient centrifugation on Percoll. Purity of mast cells in unpurified and purified preparations was lower than $5 \%$ and over $97 \%$, respectively. Mast cells at a concentration of $105 / \mathrm{m} l$ were stimulated with $1 \mu \mathrm{g} / \mathrm{m} l$ antigen for $15 \mathrm{~min}$. Values are the mean \pm SEM of 4 duplicated experiments.

tiated rapidly upon antigen stimulation and reached a plateau in $5 \mathrm{~min}$. Even in the suboptimal antigen concentration, $50 \%$ of total histamine was released.

Results of histamine release from 7 specimens prepared from a rat are shown in Fig. 2A. Mesenterium specimens released $46.4 \pm 1.3 \%(42.0-52.8 \%)$ of total histamine, indicating that variation of histamine release among specimens from a rat is small. Results of histamine release from 8 specimens prepared from different rats are shown in Fig. 2B. Mesenterium specimens released $46.5 \pm 1.9 \%$ (37.6-52.9\%) of total histamine, indicating that variation of histamine release among specimens from different rats is also small. The results of histamine release from peritoneal mast cells are shown in Fig. 2C. Unpurified and purified preparations of peritoneal mast cells released only $22.5 \%$ and

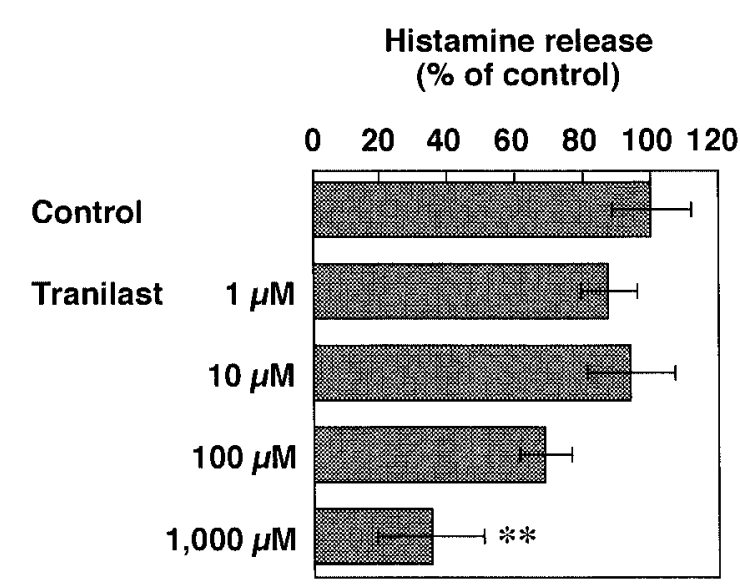

Fig. 3. Effect of tranilast on histamine release from mesenterium. Sensitized mesenterium was incubated with $1 \mu \mathrm{g}$ antigen for $15 \mathrm{~min}$. Tranilast was dissolved in dimethyl sulfoxide and added 5 min before antigen stimulation. Values are the mean \pm SEM of 4 experiments. $* * \mathrm{p}<0.01$ (Tukey-Kramer multiple comparisons test, InStat Program, GraphPad Software, San Diego, CA, USA).

$5.3 \%$ of total histamine, respectively, upon antigen stimulation. Purification reduced the histamine release from peritoneal mast cells as reported previously $[4,5]$. These results indicate that mesenteric mast cells release higher rates of histamine than peritoneal mast cells.

The effect of tranilast, an anti-allergenic agent $[1,6]$, on the histamine release was examined. Mesenterium specimens were incubated with $1 \mu \mathrm{g}$ antigen for 15 min. Tranilast was dissolved in dimethyl sulfoxide and added 5 min before antigen stimulation. The final concentration of dimethyl sulfoxide was $0.1 \%$. As shown in Fig. 3, tranilast suppressed the histamine release in a concentration-dependent manner, and the suppression at $1,000 \mu \mathrm{M}$ was statistically significant.

In the present study, we showed that mast cells in the rat mesenterium released over $50 \%$ of total histamine in an optimal experimental condition. The rate for histamine release is superior to that for peritoneal mast cells. In 1995, Yasuda et al. showed that mast cells possess integrins on their surfaces, and that adhesion to the extracellular matrix through the molecules potentiates the mast cell activation [11]. Many humoral factors are also known to induce or potentiate mast cell activation [8]. Both surfaces of mesenterium are covered by tunica serosa and mesenteric mast cells are present in connective tissues between them. There- 
fore, mesenteric mast cells might be influenced by extracellular milieu directly through adhesion molecules and indirectly through humoral factors. In contrast, peritoneal mast cells are floating single cells. In the peritoneal cavity, macrophages (about 90\%), neutrophils and eosinophils are also present [5], and peritoneal mast cells may interact with these cells both directly and indirectly. Adhesion molecules on the peritoneal mast cell, however, seem to be inactive, because unstimulated peritoneal mast cells do not adhere to dishes coated with extracellular matrix proteins (unpublished data). The difference of extracellular milieu between mesenteric mast cells and peritoneal mast cells may partly explain their different responses to $\operatorname{IgE}$ stimulation. The rat mesenterium might be a useful material for studying tissue-associated mast cell activation and regulation by surrounding cells.

\section{References}

1. Azuma, H., Banno, K., and Yoshimura, T. 1976. Br. J. Pharmacol. 58: 483-488.

2. Eisen, H. N., Belman, S., and Carsten, M. E. 1953. J. Am. Chem. Soc. 75: 4583-4585.

3. Enerbäck, L. and Svensson, I. 1980. J. Immunol. Methods 39: 135-145.

4. Inagaki, N., Kawasaki, H., Ueno, M., Nagai, H., and Koda, A. 1994. Life Sci. 54: 1403-1409.

5. Inagaki, N., Kawasaki, H., and Nagai, H. 1995. Inflamm. Res. 44: 541-547.

6. Koda, A., Nagai, H., Watanabe, S., Yanagihara, Y., and Sakamoto, K. 1976. J. Allergy Clin. Immunol. 57: 396-407.

7. Matsuura, N., Mori, H., Nagai, H., and Koda, A. 1992. Folia Pharmacol. Japon. 100: 495-501.

8. Nakajima, K., Hirai, K., Yamaguchi, K., Takaishi, T., Ohta, K., Morita, Y., and Ito, K. 1992. Biochem. Biophys. Res. Commun. 183: 1078-1083.

9. Wells, E. and Mann, J. 1983. Biochem. Pharmacol. 32: 837-842.

10. Yamatodani, A., Fukuda, H., Wada, H., Iwaeda, T., and Watanabe, T. 1985. J. Chromatogr. 344: 115-123.

11. Yasuda, M., Hasunuma, Y., Adachi, H., Sekine, C., Sakanishi, T., Hashimoto, H., Ra, C., Yagita, H., and Okumura, K. 1995. Int. Immunol. 7: 251-258. 